\title{
PEMANFAATAN LIMBAH PLASTIK SEBAGAI BAHAN BAKU PEMBUATAN BAHAN BAKAR ALTERNATIF
}

\section{THE UTILIZATION OF PLASTIC WASTE AS RAW MATERIAL FOR PRODUCING ALTERNATIVE FUEL}

\author{
Jatmiko Wahyudi*, Hermain Teguh Prayitno, Arieyanti Dwi Astuti \\ Badan Perencanaan Pembangunan Daerah Kabupaten Pati \\ *Email : jatmiko_tkuns@yahoo.com
}

Naskah Masuk: 14 Maret 2018

Naskah Revisi: 4 April 2018
Naskah Diterima: 7 April 2018

\begin{abstract}
The amount of waste generation continued to increase in Indonesia due to economic development and population growth. In addition, the diversity of solid waste becomes another problem since products made from plastics became widely used and were discarded in large amounts. Plastic waste can be converted into fuel through pirolisis in order to reduce the amount of plastic waste as well as to produce alternative fuel. Pyrolysis is a process of thermal degradation in the absence of oxygen. The objective of this study is to investigate and to compare the performace of fuel produced by pyrolisys, kerosene and diesel oil. The performance of those fuels is investigated in 4 parameters including density, burning time, temperature of water and the volume of water evaporated. The result of this study are 1) the density $0.8 \mathrm{~g} / \mathrm{ml}$; burning time 4.02 minutes; water temperature $75^{\circ} \mathrm{C}$ and water evaporated $12.6 \mathrm{ml}$. 2) Compared to kerosene and diesel oil, the quality of the fuel is lower than kerosene and higher than diesel oil in all parameters.
\end{abstract}

Keywords: fuel oil, plastic waste, pyrolysis

\begin{abstract}
ABSTRAK
Pertumbuhan penduduk dan ekonomi menyebabkan terjadinya peningkatan produksi sampah khususnya sampah plastik. Pirolisis merupakan proses perekahan atau pemecahan rantai polimer menjadi senyawa yang lebih sederhana melalui proses thermal (pemanasan/pembakaran) dengan tanpa maupun sedikit oksigen. Sampah plastik bisa diurai dan diubah menjadi bahan bakar yang memiliki nilai kalor yang tinggi melalui proses pirolisis. Penelitian ini bertujuan untuk mengetahui dan membandingkan kemampuan minyak hasil pirolisis plastik dengan minyak tanah dan solar dalam hal massa jenis, lama pembakaran, temperatur air dan volume air yang hilang (menguap) saat dimasak menggunakan minyak tersebut. Hasil penelitian menunjukkan bahwa 1) massa jenis minyak pirolisis adalah $0,8 \mathrm{~g} / \mathrm{ml}$. Waktu yang dibutuhkan untuk membakar habis suatu benda adalah 4,02 menit. Pemasakan air menggunakan bahan bakar minyak pirolisis menghasilkan temperatur $75^{\circ} \mathrm{C}$ pada waktu pemasakan 4 menit dengan volume air yang hilang (menguap) sebesar 12,6 ml. 2) Dari 4 parameter yang diamati, kualitas minyak pirolisis berada di bawah minyak tanah namun di atas minyak solar.
\end{abstract}

Kata kunci : minyak bakar, limbah plastik, pirolisis 


\section{PENDAHULUAN}

Produksi sampah nasional menunjukkan tren yang terus meningkat seiring dengan terjadinya pertumbuhan ekonomi dan peningkatan jumlah penduduk. Salah satu jenis sampah yang menjadi perhatian adalah sampah plastik. Kontribusi sampah plastik terhadap total produksi sampah nasional mencapai $15 \%$ dengan pertumbuhan rata-rata mencapai $14,7 \%$ per tahun dan menempatkan sampah plastik sebagai kontributor terbesar kedua setelah sampah organik (Kholidah dkk, 2018; Dokhikhah dkk, 2015; Trihadiningrum dkk, 2006). Studi di berbagai kota Indonesia menunjukkan kontribusi sampah plastik terhadap total sampah kota di Indonesia bervariasi antara lain Jakarta (14\%), Surabaya (10,8\%), Palangkaraya (15\%) (Dokhikhah dkk, 2015; Aprilia dkk, 2012; Permana dkk, 2010).

Persentase kontribusi sampah plastik di Indonesia tidak jauh berbeda dengan Malaysia (14\%) dan Thailand (16\%) namun lebih rendah dibandingkan Singapura (27,3\%) (AOP, 2007). Namun secara riil, produksi sampah plastik di Indonesia sangat besar sebab secara total produksi sampah Indonesia mencapai 189 kilo ton/hari jauh lebih besar dibandingkan dengan negara-negara di Asia Tenggara (Kholidah dkk, 2018). Hal ini disebabkan jumlah penduduk Indonesia yang lebih besar dibandingkan dengan jumlah penduduk negara-negra di Asia Tenggara.

Pengelolaan sampah plastik
menjadi masalah sebab plastik merupakan material yang tidak bisa terdekomposisi secara alami (non biodegradable) sehingga pengelolaan sampah plastik dengan landfill maupun open dumping tidak tepat dilakukan. Pengelolaan sampah plastik dengan cara pembakaran dapat menyebabkan dampak negatif terhadap lingkungan berupa terjadinya pencemaran udara khususnya emisi dioxin yang bersifat karsinogen. Pengelolaan sampah plastik lainnya adalah dengan mendaur ulang sampah plastik menjadi bentuk lain, namun proses daur ulang ini hanya akan merubah sampah plastik menjadi bentuk baru bukan menanggulangi volume sampah plastik sehingga ketika produk daur ulang plastik sudah kehilangan fungsinya maka akan kembali menjadi sampah plastik. Oleh karenanya diperlukan alternatif lain untuk menangani volume sampah plastik ini.

Salah satu alternatif penanganan sampah plastik adalah dengan melakukan proses daur ulang (recycle). Pirolisis sampah plastik merupakan salah satu bentuk proses daur ulang dengan mengubah plastik menjadi bahan bakar. Selain bermanfaat untuk mengurangi jumlah sampah plastik, pirolisis sampah plastik juga bermanfaat untuk menyediakan bahan bakar dengan nilai energi yang cukup tinggi. Secara umum, kurang lebih $950 \mathrm{ml}$ minyak bakar bisa diperoleh dari pirolisis $1 \mathrm{~kg}$ plastik Polyolefin misalnya Polypropylene, Polyethylene dan Polystyrene (Thorat dkk, 2013).

Studi-studi mengenai pembuatan bahan bakar dari sampah plastik telah dilakukan. Pratama dan Saptoadi (2014) serta Kadir (2012) melakukan studi pirolisis sampah plastik dengan memvariasikan komposisi dan jenis bahan baku plastik. Sementara studi yang dilakukan oleh Osueke dan Ofondu (2011) berfokus pada pirolisis yang berlangsung pada suhu tinggi dan pengaruh penggunaan katalis terhadap kualitas produk.

Namun pada umumnya studi yang telah dilakukan menggunakan instalasi pirolisis kompleks yang lebih diarahkan untuk skala industri. Studi yang meneliti proses pirolisis sampah plastik pada 
instalasi sederhana (skala kecil) belum banyak dilakukan. Instalasi pirolisis sederhana dengan kapasitas produksi rendah dan biaya investasi yang tidak terlalu tinggi saat ini banyak dikembangkan terutama di daerahdaerah. Instalasi pirolisis telah digunakan di Tempat Pembuangan Akhir (TPA) Sukoharjo Kabupaten Pati. Instalasi tersebut berfungsi untuk mengolah limbah plastik sehingga jumlah plastik yang terkumpul di TPA tersebut dapat dikurangi.

Oleh karena itu, perlu dilakukan studi mengenai unjuk kerja instalasi pirolisis sederhana untuk diketahui kualitas produk (minyak bakar) yang dihasilkan. Tujuan dari penelitian ini adalah untuk mengetahui dan membandingkan kemampuan minyak hasil pirolisis plastik dengan minyak tanah dan solar dalam hal massa jenis, lama pembakaran, temperatur air dan volume air yang hilang (menguap) saat dimasak menggunakan minyak tersebut.

\section{TINJAUAN PUSTAKA}

\section{Plastik}

Plastik merupakan material terbuat darinafta yang merupakan produk turunan minyak bumi yang diperoleh melalui proses penyulingan. Karakteristik plastik yang memiliki ikatan kimia yang sangat kuat sehingga banyak material yang dipakai oleh masyarakat berasal dari plastik. Namun plastik merupakan material yang tidak bisa terdekomposisi secara alami (non biodegradable) sehingga setelah digunakan, material yang berbahan baku plastik akan menjadi sampah yang sulit diuraikan oleh mikroba tanah dan akan mencemari lingkungan.

Berdasarkan jenis produknya, terdapat 6 jenis plastik yaitu Polyethylene Terephthalate (PET), High Density Polyethylene (HDPE), Polyvinyl Chloride (PVC), Low Density
Polyethylene (LDPE), Polypropylene (PP), Polystyrene (PS) dan Other. (Hartulistiyoso, dkk, 2014). Umumnya sampah plastik memiliki komposisi $46 \%$ Polyethylene (HDPE dan LDPE), $16 \%$ Polypropylene (PP), 16\% Polystyrene (PS), 7\% Polyvinyl Chloride (PVC), 5\% Polyethylene Trephthalate (PET), 5\% Acrylonitrile-Butadiene-Styrene (ABS) dan polimer-polimer lainnya. Lebih dari $70 \%$ plastik yang dihasilkan saat ini adalah Polyethylene (PE), Polpropylene (PP), Polystyrene (PS), dan Polyvinyl Chloride (PVC) sehingga sebagian besar studi yang dilakukan berhubungan dengan keempat jenis polimer tersebut (Praputri dkk, 2016).

Tabel 1.

Karakteristik Jenis Plastik

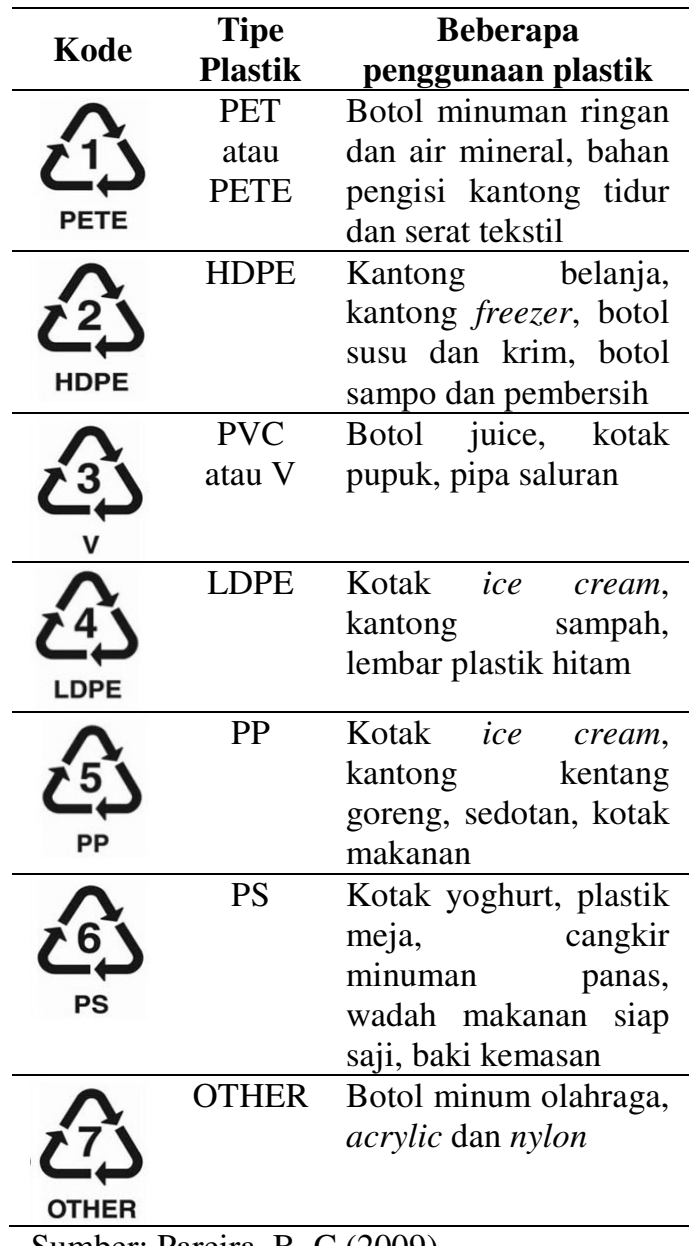

Sumber: Pareira, B. C (2009) 
Berdasarkan asalnya, sampah plastik dibedakan menjadi sampah plastik industri dan sampah plastik rumah tangga. Sampah plastik industri berasal dari industri pembuatan plastik maupun industri yang bergerak di bidang pemrosesan. Sampah plastik rumah tangga dihasilkan terkait dengan aktivitas manusia sehari-hari misalnya plastik kemasan, plastik tempat makanan atau minuman (Syamsiro dkk, 2013).

Berdasarkan sifatnya, plastik dapat dikelompokkan menjadi dua macam yaitu thermoplastic dan thermosetting. Thermoplastic adalah bahan plastik yang bila digunakan untuk membuat material tertentu dapat didaur ulang dan dibuat menjadi bentuk material yang lain melalui proses pemanasan. Contoh thermoplastic antara lain yaitu Polyethylene, Polypropylene, Nylon, Polycarbonate. Thermosetting adalah plastik yang jika telah dibuat dalam material tertentu, tidak dapat dicairkan untuk didaur ulang atau dibuat produk lain. Contoh plastik yang termasuk thermosetting antara lain Phenol formaldehyde, Urea Formaldehyde, Melamine Formaldehyde (Das \& Pandey, 2007; Surono, 2013).

\section{Pirolisis}

Ada beberapa metode yang dapat digunakan untuk mengkonversi sampah plastik menjadi bahan bakar cair, antara lain: pyrolysis, thermal cracking, and catalitic cracking. Diantara ketiga metode tersebut, metode pirolisis adalah metode yang dianggap paling menjanjikan.

Pirolisis berasal dari dua kata yaitu pyro yang berarti panas dan lysis yang berarti penguraian atau degradasi, sehingga pirolisis berarti penguraian biomassa oleh panas pada suhu lebih dari $150^{\circ} \mathrm{C}$. Pirolisis merupakan proses thermal cracking yaitu proses perekahan atau pemecahan rantai polimer menjadi senyawa yang lebih sederhana melalui proses thermal (pemanasan/pembakaran) dengan tanpa maupun sedikit oksigen. Pirolisis merupakan proses endotermis artinya proses pirolisis hanya bisa terjadi ketika dalam sistem diberikan energi panas. Energi panas yang dibutuhkan pada proses ini dapat bersumber dari tenaga listrik maupun dari tungku pembakaran dengan bahan bakar berupa limbah kayu seperti potongan-potongan kayu, serbuk gergaji, dan lain-lain. Istilah lain dari pirolisis adalah "destructive distillation" atau destilasi kering, merupakan proses penguraian yang tidak teratur dari bahan-bahan organik yang disebabkan oleh adanya pemanasan tanpa berhubungan dengan udara luar.

Plastik yang mengalami proses pirolisis akan terdekomposisi menjadi material-material pada fase cair dalam bentuk minyak bakar, fase gas berupa campuran gas yang dapat terkondensasi maupun tidak dapat terkondensasi dan fase padat berupa residu maupun tar (Hamidi dkk, 2013). Dibandingkan dengan bio-fuel seperti biodisel maupun bioetanol, minyak hasil pirolisis plastik memiliki beberapa kelebihan. Minyak hasil pirolisis tidak mengandung air sehingga nilai kalorinya lebih besar. Selain itu, minyak hasil pirolisis tidak mengandung oksigen sehingga tidak menyebabkan korosi (Hidayah \& Syafrudin, 2018).

\section{METODE PENELITIAN}

\section{Bahan dan Alat}

Bahan dan alat yang digunakan pada penelitian ini berupa:

1. Material plastik yang digunakan sebagai bahan baku dalam penelitian ini adalah plastik dari jenis polyprophelene (PP) berupa gelas plastik yang digunakan sebagai kemasan air minum dalam kemasan (AMDK), gelas plastik ini diperoleh dari pengepul. 
2. Minyak tanah dan solar yang digunakan sebagai bahan bakar pembanding diperoleh dari Stasiun Pompa Bensin Umum (SPBU) Pertamina sehingga spesifikasi bahan bakar yang diperoleh sesuai standar Pertamina.

3. 1 set reaktor pirolisis

4. Air sebagai pendingin

5. Timbangan digital
6. Stopwatch

7. Gelas ukur

8. Termometer

9. Pipet

10. Tungku pembakaran

11. Cawan

Rangkaian alat pirolisis yang digunakan pada penelitian ini disajikan pada Gambar 1.

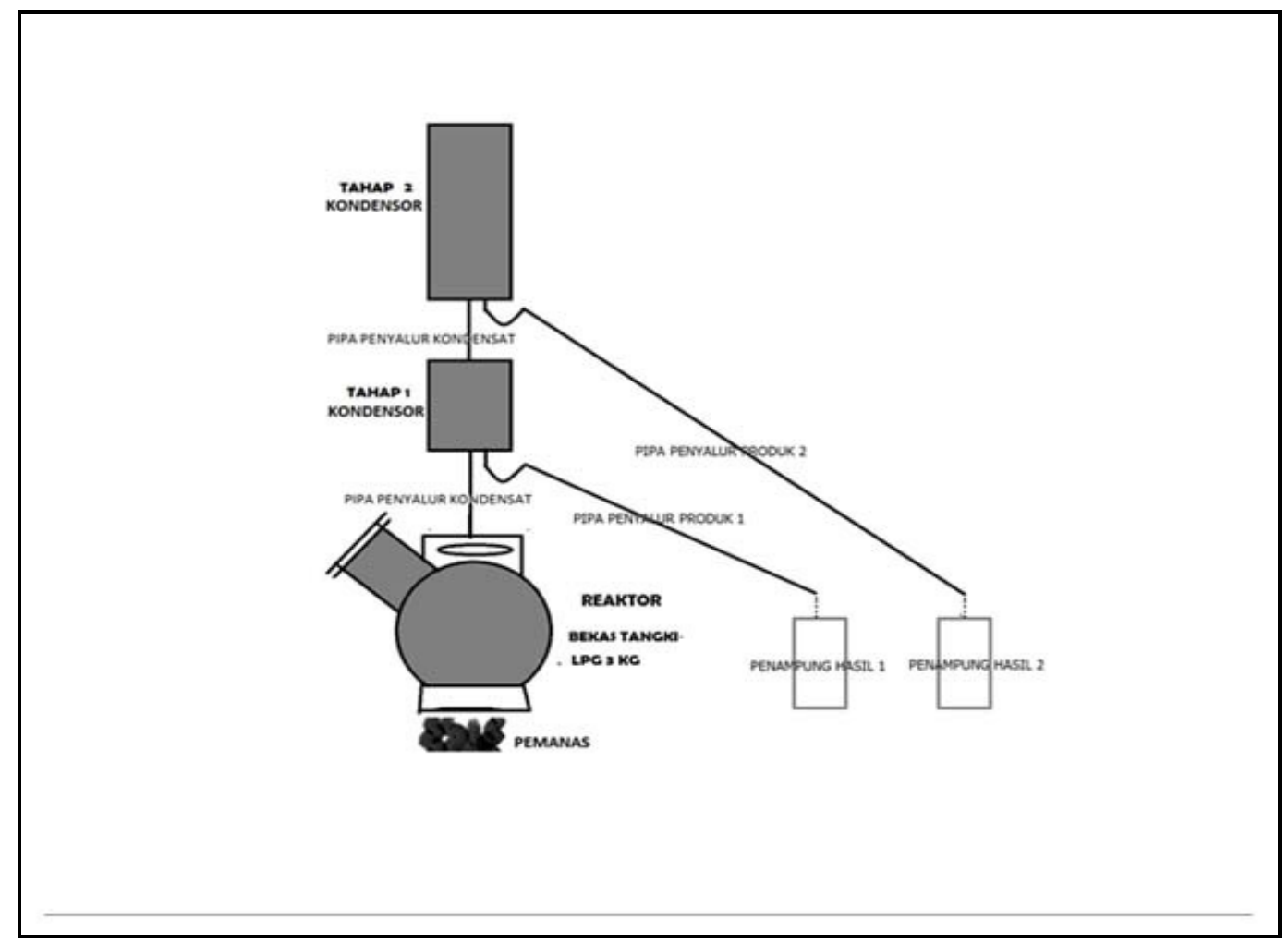

Gambar 1.

Rangkaian Alat Pirolisis Plastik

\section{Prosedur Eksperimen}

Gelas plastik dalam kondisi kering sebanyak 200 gram dimasukkan ke dalam alat pirolisis yang dilengkapi sistem pendingin dan penampung destilat. Gelas plastik (PP) pada fase padat selanjutnya diubah menjadi fase cair (minyak) dengan menggunakan proses thermo cracking (pirolisis).

Alasan pemilihan plastik jenis PP adalah minyak bakar yang dihasilkan dari pirolisis PP memiliki kualitas yang lebih bagus dibandingkan PVC maupun PET (Thorat dkk, 2013). Plastik PP merupakan jenis plastik yang paling banyak digunakan dalam kehidupan sehari-hari karena memiliki sifat mekanis yang baik dengan massa jenis yang rendah, ketahanan panas dan kelembaban serta kestabilan dimensi yang baik. Selain itu, plastik jenis PP mempunyai susunan molekul hidrokarbon yang paling sederhana dbandingkan jenis plastik lainnya (Ermawati, 2011). 
Proses perubahan fase dari padat menjadi cair berlangsung dalam dua tahap. Tahap pertama, perubahan fase padat menjadi gas dilakukan dengan cara memanaskan gelas plastik (padat) dengan menggunakan kompor LPG. Tahap kedua, perubahan fase gas menjadi cair dengan cara mengkondensasikan gas yang terbentuk pada tahap pertama sehingga diperoleh destilat berupa minyak (cair).

\section{Analisis}

Analisis massa jenis minyak hasil pirolisis, minyak tanah dan solar dilakukan dengan cara mengukur volume dan massa masing-masing sampel. Tiaptiap sampel diambil $5 \mathrm{ml}$ dengan gelas ukur selanjutnya sampel ditimbang untuk diperoleh massa sampel. Massa jenis sampel dihitung dengan persamaan (1).

$$
\rho=\frac{m}{V} \ldots \ldots \ldots \ldots \ldots \ldots
$$

dimana $\rho$ adalah massa jenis, $m$ adalah massa sampel dan $\mathrm{V}$ adalah volume sampel.

Analisis unjuk kerja minyak hasil pirolisis, minyak tanah dan solar dilakukan dengan menganalisis lama pembakaran masing-masing sampel bahan bakar, unjuk kerja sampel dalam menaikkan suhu (memanaskan) air dan mengukur volume air yang tersisa setelah dipanaskan dengan menggunakan masing-masing sampel bahan bakar.

Analisis lama pembakaran dilakukan dengan mengambil $5 \mathrm{ml}$ masing-masing sampel bahan bakar yang dimasukkan ke 3 tungku pembakaran yang berbeda. Waktu yang dibutuhkan masing-masing sampel bahan bakar untuk membakar material sampai habis akan dihitung dan dianalisis.

Analisis unjuk kerja sampel bahan bakar dalam memanaskan air dilakukan dengan menggunakan masing-masing sampel sebagai bahan bakar untuk memanaskan $15 \mathrm{ml}$ air. Proses pemanasan dilakukan selama 4 menit dan selanjutnya temperatur air yang dipanaskan dengan 3 sampel bahan bakar akan diukur dan dianalisis.

Analisis unjuk kerja sampel bahan bakar dalam menguapkan air dilakukan dengan mengukur memanaskan $15 \mathrm{ml}$ air selama 4 menit. Selanjutnya volume air yang tersisa setelah dilakukan pemanasan dengan 3 sampel bahan bakar yang berbeda diukur dan dianalisis.

\section{HASIL DAN PEMBAHASAN}

\section{Massa Jenis}

Hasil penghitungan massa jenis minyak pirolisis plastik, minyak tanah \& minyak solar disajikan pada Gambar 2.

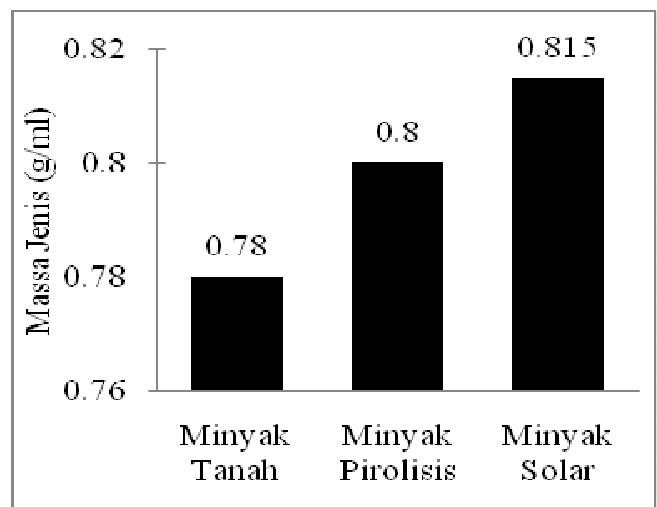

Gambar 2.

Grafik Massa Jenis Minyak

Sumber: Data diolah (2013)

Gambar 2 menunjukkan bahwa massa jenis minyak hasil pirolisis plastik jenis PP sebesar 0,8 g/ml lebih rendah dari massa jenis minyak solar namun lebih tinggi dari massa jenis minyak tanah. Massa jenis minyak solar dan minyak tanah ini masuk dalam kisaran spesifikasi standar menurut Kementerian ESDM (2006) yaitu $0,815-0,87 \mathrm{gr} / \mathrm{ml}$ untuk minyak solar dan $0,79-0,83 \mathrm{gr} / \mathrm{ml}$ untuk minyak tanah.

Suatu benda yang memiliki massa jenis yang semakin tinggi maka semakin besar pula massa setiap volumenya. Minyak solar memiliki massa paling besar pada setiap volumenya 
dibandingkan dari ketiga jenis minyak yang diteliti. Sedangkan minyak tanah memiliki massa yang paling rendah pada setiap volumenya. Hal ini mengindikasikan bahwa minyak solar masih memiliki banyak pengotor karena dihasilkan dari proses penyulingan bahan bakar mentah pertama sehingga kualitasnya masih berada di bawah minyak tanah dan minyak pirolisis.

\section{Lama Pembakaran}

Lama pembakaran digunakan untuk mengetahui waktu yang dibutuhkan minyak untuk membakar habis suatu benda. Hasil yang diperoleh dapat dilihat pada Gambar 3.

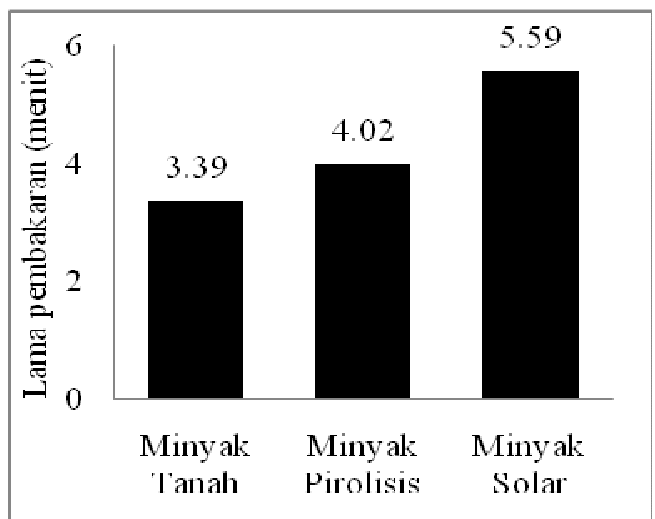

Gambar 3.

Grafik Lama Pembakaran Minyak Sumber: Data diolah (2013)

Berdasarkan Gambar 3 diketahui bahwa minyak solar menghasilkan waktu pembakaran yang paling lama dibandingkan minyak tanah dan minyak pirolisis yaitu 5,59 menit. Hal ini dikarenakan minyak solar memiliki titik nyala yang paling tinggi diantara kedua minyak lainnya yaitu $55^{\circ} \mathrm{C}$ (Kementerian ESDM, 2006), sedangkan titik nyala minyak tanah adalah $47,8^{\circ} \mathrm{C}$ (Kahar, 2007).

Titik nyala berhubungan langsung dengan mudah atau tidaknya suatu bahan bakar dapat terbakar. Titik nyala yang semakin rendah menyebabkan zat tersebut semakin mudah dibakar, sehingga sifat fisis ini sangat penting sekali sebagai syarat suatu zat dikatakan sebagai bahan bakar. Walaupun dalam penelitian ini tidak dihitung titik nyala minyak pirolisis, gambar 3 bisa mengartikan bahwa minyak pirolisis memiliki titik nyala yang lebih besar dari minyak tanah tapi lebih kecil dari minyak solar.

\section{Temperatur Air}

Pada penelitian ini, minyak hasil pirolisis plastik diuji dengan menggunakannya sebagai bahan bakar untuk memasak air sehingga dapat diketahui besarnya temperatur air. Temperatur air yang dihasilkan dari pemasakan menggunakan minyak pirolisis akan dibandingkan dengan temperatur air hasil pemasakan menggunakan minyak tanah dan minyak solar. Temperatur air yang dihasilkan disajikan pada Gambar 4.

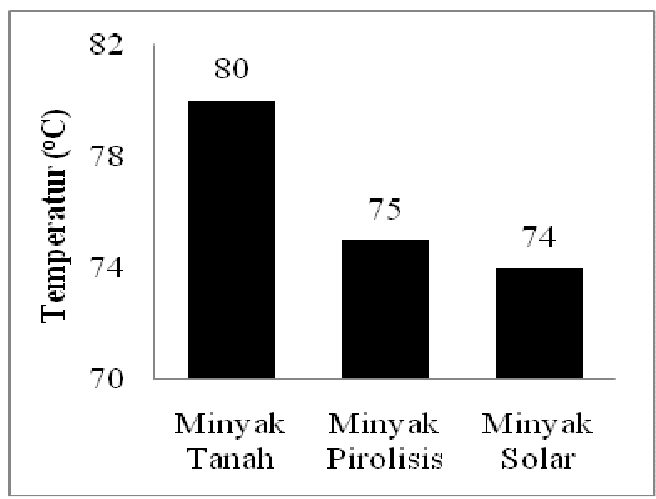

Gambar 4.

Temperatur Air Yang Dipanaskan Sumber: Data diolah (2013)

Berdasarkan Gambar 3 dan Gambar 4 terlihat adanya hubungan yang berbanding terbalik, dimana semakin lama pembakaran maka temperatur air yang dihasilkan akan semakin rendah. Pengukuran temperatur ini dilakukan pada waktu yang sama pada masingmasing jenis minyak. Ketika cawan air yang dibakar menggunakan minyak tanah sudah panas, maka cawan air yang 
dibakar menggunakan minyak pirolisis mulai panas namun cawan air yang dibakar menggunakan minyak solar belum panas.

Minyak solar membutuhkan waktu yang paling lama untuk terbakar karena memiliki titik nyala paling tinggi $\left(55^{\circ} \mathrm{C}\right)$ diantanya kedua minyak lainnya sehingga air yang dimasak menggunakan minyak solar memiliki temperatur yang paling rendah $74^{\circ} \mathrm{C}$. Sedangkan air yang dimasak menggunakan bahan bakar minyak pirolisis memiliki temperatur $75^{\circ} \mathrm{C}$. Temperatur ini berada diantara minyak tanah dan minyak solar karena minyak pirolisis plastik memiliki titik nyala yang juga berada diantara minyak tanah dan minyak solar. Begitu pula minyak tanah yang menghasilkan temperatur pada air paling tinggi yaitu $80^{\circ} \mathrm{C}$, karena memiliki titik nyala paling rendah $\left(47,8^{\circ} \mathrm{C}\right)$.

\section{Volume Air yang Hilang}

Banyaknya volume air yang hilang akibat pemanasan yang dilakukan dengan menggunakan masing-masing sampel bahan bakar disajikan pada Gambar 5 .

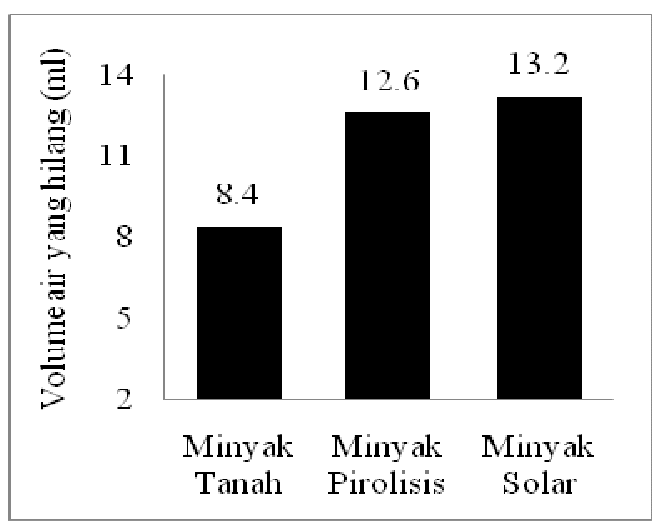

Gambar 5.

Grafik Volume Air yang Menguap Sumber: Data diolah (2013)

Selain dengan mengukur temperatur pada pemasakan air, uji kemampuan minyak pirolisis juga dilakukan dengan mengukur banyaknya volume air yang hilang (menguap) pada proses pemanasan air menggunakan minyak tersebut. Volume air yang menguap paling tinggi dihasilkan dari pemasakan air menggunakan minyak solar (13,2 ml), diikuti minyak pirolisis (12,6 ml) dan yang paling rendah adalah minyak tanah $(8,4 \mathrm{ml})$. Volume air yang menguap ini seharusnya memiliki hubungan yang berbanding lurus dengan temperatur air pada Gambar 4. Namun pada kenyataanya, Gambar 4 dan Gambar 5 memiliki hubungan berbanding terbalik. Minyak solar yang menghasilkan temperatur air yang dimasak paling rendah justru mampu menguapkan air paling tinggi. Begitu pula dengan minyak tanah, yang memiliki temperatur air paling tinggi justru hanya mampu menguapkan air dengan volume paling rendah. Hal ini berkaitan dengan titik nyala minyak. Semakin tinggi titik nyala maka semakin lama nyala dari pembakaran minyak tersebut. Hal ini sesuai dengan Gambar 3 yang menggambarkan bahwa minyak solar memiliki waktu pembakaran yang paling lama, diikuti minyak pirolisis dan minyak tanah.

\section{KESIMPULAN DAN SARAN}

\section{Kesimpulan}

Massa jenis minyak pirolisis adalah $0,8 \mathrm{~g} / \mathrm{ml}$. Sedangkan waktu yang dibutuhkan untuk membakar habis suatu benda adalah 4,02 menit. Pemasakan air menggunakan bahan bakar minyak pirolisis menghasilkan temperatur $75^{\circ} \mathrm{C}$ pada waktu pemasakan 4 menit dengan volume air yang hilang (menguap) sebesar 12,6 ml.

Jika dibandingkan dengan kualitas minyak tanah dan minyak solar, kualitas minyak pirolisis berada di bawah minyak tanah namun diatas solar berdasarkan indikator massa jenis, lama pembakaran, temperatur air dan volume air yang hilang (menguap) saat dimasak menggunakan minyak tersebut. 
Saran

Untuk bisa mendapatkan teknologi tepat guna dari pirolisis plastik ini, bahan bakar yang digunakan untuk memanaskan alat pirolisis sebaiknya menggunakan bahan bakar yang murah dan ramah lingkungan (biogas) sehingga diharapkan hasil yang diperoleh lebih murah dan aplikatif.

Perlu dilakukan pengujian standar spesifikasi bahan bakar minyak pirolisis agar dapat diketahui pemanfaatannya, termasuk kekurangan dan kelebihannya dibanding bahan bakar minyak yang saat ini sudah ada di pasaran.

\section{DAFTAR PUSTAKA}

Asian Productivity Organization (AOP). (2007). Solid Waste Management: Issues and Challenges in Asia. Tokyo

Das, S., Pandey, S. (2007). Pyrolysis and Catalytic Cracking of Municipal Plastic Waste for Recovery of Gasoline Range

Hydrocarbons. Theses. National Institute of Technology Rourkela

Departemen Energi dan Sumber Daya Mineral Republik Indonesia. (2006). Keputusan Direktur Jenderal Minyak dan Gas Bumi Nomor 3675 K/24/DJM/2006 tentang Standar dan Baku Mutu (Spesifikasi) Bahan Bakar Minyak.

Dhokhikah,' Y., Trihadiningrum, Y., Sunaryo, S. (2015). Community participation in household solid waste reduction in Surabaya, Indonesia. Resources, Conservation and Recycling, 102, 153-162

Ermawati, R. (2011). Konversi Limbah Plastik Sebagai Sumber energi Alternatif. Balai Besar Kimia dan Kemasan.

Kementerian
Perindustrian. Jurnal Riset Industri, 5(3), 257-263

Aprilia, A., Tezuka, T., Spaargaren, G. (2012). Inorganic and hazardous solid waste management: Current status and challenges for Indonesia. Procedia Environmental Sciences, 17, 640647

Hidayah, N, Syafrudin. (2018). A Review on Landfill Management in the Utilization of Plastic Waste as an Alternative Fuel. Proceeding The $2^{\text {nd }}$ International Conference on Energy, Environmental and Information System (ICENIS 2017). Semarang: Universitas Diponegoro 15-16 Agustus 2017

Hamidi, N., Tebyanian, F., Massoudi, R., Whitesides, L. (2013). Pyrolysis of Household Plastic Wastes. British Journal of Applied Science \& Technology, 3(3), 417439

Hartulistiyoso, E., Sigiroa, F., Yulianto, M. (2015). Temperature distribution of the plastics Pyrolysis process to producefuel at $450^{\circ} \mathrm{C}$. Procedia Environmental Sciences, 28, 234 - 241

Kadir. (2012). Kajian Pemanfaatan Sampah Plastik Sebagai Sumber Bahan Bakar Cair. Dinamika Jurnal Ilmiah Teknik Mesin, 3(2), 223-228

Kholidah, N., Faizal, M., Said, M. (2018). Polystyrene P lastic Waste Conversion into Liquid Fuel with Catalytic Cracking Process Using $\mathrm{Al}_{2} \mathrm{O}_{3}$ as Catalyst. Science \& Technology Indonesia, 3, $1-6$

Osueke C. O., Ofondu, I. O. (2011). Conversion of Waste Plastics (Polyethylene) to Fuel by Means of Pyrolysis. International Journal 
of Advanced Engineering Sciences and Technologies, 4(1), 21-24

Pareira, B. C. (2009). Daur Ulang Limbah

Plastik.http://www.erorecycle.vic.g ov.au

Permana, T. J., Trihadiningrum, Y. (2010). Kajian Pengadaan dan Penerapan Tempat Pengolahan Sampah Terpadu (TPST) di TPA Km.14 Kota Palangka Raya. Prosiding Seminar Nasional Manajemen Teknologi XI. Surabaya: Institut Sepuluh Nopember 6 Pebruari 2010

Praputri, E., Mulyazmi, E., Sari, M., Martynis. (2016). Pengolahan Limbah Plastik Polypropylene Sebagai Bahan Bakar Minyak (BBM) dengan Proses Pyrolysis. Seminar Nasional Teknik KimiaTeknologi Oleo Petro Kimia Indonesia. Pekanbaru

Pratama, N. P., Saptoadi, H. (2014). Characteristics of Waste Plastics Pyrolytic Oil and Its Applications as Alternative Fuel on Four Cylinder Diesel Engines. International Journal of Renewable Energy Development, 3(1), 13-20

Surono, U. B. (2013). Berbagai Metode Konversi Sampah Plastik Menjadi Bahan Bakar Minyak. Jurnal Teknik, 3(1), 32-40

Syamsiro, M., Saptoadi, H., Norsujianto, T., Noviasri, P., Cheng, S., Alimuddin, Z., Yoshikawaa, K. (2013). Fuel Oil Production from Municipal Plastic Wastes in Sequential Pyrolysis and Catalytic Reforming Reactors. Energy Procedia, 47, 180 - 188

Thorat, P.V. Warulkara, S \& Sathone, H. (2013). Thermofuel - “ Pyrolysis of waste plastic to produce Liquid Hydroocarbons". Advances in Polymer Science and Technology: An International Journal, 3(1), 1418

Trihadiningrum, Y. Wigjosoebroto, S. Simatupang, N.D. \& Damayanti, O. (2006). Reduction capacity of plastic component in municipal solid waste of Surabaya City, Indonesia. Environmental Technology and Management Conference 2006. Bandung, September 7-8, 2006.

\section{BIODATA PENULIS}

Jatmiko Wahyudi, lahir 5 Oktober 1979 di kota Pati, Jawa Tengah. Gelar Sarjana Teknik (ST) diperoleh dari Jurusan Teknik Kimia, Universitas Sebelas Maret Surakarta. Pendidikan S2 diperoleh melalui program dobel degree di jurusan Ilmu Lingkungan Universitas Padjadjaran, Bandung dan Jurusan Environmental and Energy Management, The University of Twente, Belanda. Saat ini bekerja sebagai peneliti di Badan Perencanaan Pembangunan Daerah (BAPPEDA) Kabupaten Pati.

Hermain Teguh Prayitno, lahir 11 April 1970 di kota Rembang Jawa Tengah. Magister Ilmu Lingkungan dari Universitas Diponegoro (UNDIP) Semarang tahun 2008. Saat ini bekerja sebagai peneliti di Badan Perencanaan Pembangunan Daerah (BAPPEDA) Kabupaten Pati.

Arieyanti Dwi Astuti, lahir 24 Agustus 1984 di kota Pati Jawa Tengah. Sarjana (S1) dari Universitas Diponegoro (UNDIP) Semarang Jurusan Teknik Lingkungan Tahun 2007. Saat ini bekerja sebagai peneliti di Badan Perencanaan Pembangunan Daerah (BAPPEDA) Kabupaten Pati 